\title{
EFFECT OF COOKING METHODS AND RICE VARIETY ON THE SENSORY QUALITY AND CONSUMER ACCEPTANCE
}

\author{
Annis Catur Adi ${ }^{1}$, Mahmud Aditya Rifqi ${ }^{2}$, Merryana Adriani ${ }^{2}$, Farapti $^{4}$, Nila Reswari Haryana ${ }^{* 5}$, \\ Junaida Astina ${ }^{6}$ \\ ${ }^{1-5}$ Health Nutrition Departement, Faculty of Public Health, Universitas Airlangga, Indonesia \\ ${ }^{6}$ Food and Nutrition Program, Department of Nutrition and Dietetics, Faculty of Allied Health Sciences, \\ Chulalongkorn University, Thailand \\ *E-mail: nila_reswari@gmail.com
}

\begin{abstract}
Rice is the staple food of Indonesian which has superior taste which made it rooted in the eating culture in Indonesia. Nowadays, there is still limited research comparing cooking methods in various rice varieties. This study aim to analyze the effect of various cooking methods and rice variety on sensory quality. There were two cooking methods tested, traditional method that combines boiling and steaming, and rice cooker steaming method. Sensory test (quality characteristic) and acceptance test were measured using hedonic scale on 30 semi-trained panelist to evaluate the effect of cooking method on four rice variety, that are white rice Berlian Sae, white rice Super Slyp, brown rice, and black rice. Statistical test used was ANOVA and continued with Duncan test. Results showed differences in ratio of water and cooking time of various types of rice with different methods. White rice (Slyp Super) with conventional cooking methods was more acceptable to panelist with the characteristics of bright colors, smell, neutral taste, and delicate texture. There was a significant difference in panelist acceptance based on type of rice $(p<0.05)$ which brown rice and black rice had lower acceptability than white rice. There was no significant difference in acceptance by cooking method ( $p>0.05$ ), but there was a tendency that traditional method has higher acceptability. Color indicator became main indicator for panelist determined overall acceptability, so that it can be considered in the development of rice cooking methods.
\end{abstract}

Keywords: rice variety, cooking methods, sensory evaluation

\section{INTRODUCTION}

Rice is staple food of Indonesian people with increasing consumption levels. According to Ministry of Agriculture data (2017) Indonesian people rice consumption is $100.57 \mathrm{~kg} /$ capita/year with growth rate of $2.22 \%$ annually. Rice has superiority in taste and processing so that it is rooted in eating culture in Indonesia.

Rice is part of paddy grain besides husks. Among various types of cereals, rice has the most varieties, which is more than 120,000 species (IRRI, 1991). Types of rice commonly consumed in Indonesia are white rice, brown rice and black rice. The biggest part of rice $(80-85 \%)$ is starch (amylose and amylopectin). Composition of this complex carbohydrate influences the characteristics of rice especially texture (Lyon et al., 2000; Wada et al., 2006; Lum et al., 2017).

Difference in rice colour caused by diversity of genes contained and affects the color of outer portion of rice called aleuron. Each rice variety has different characteristic (Yang et al., 2010). Different varieties in rice can also affect rice characteristic, including physicochemical, morphological, and taste (Yadav et al., 2007).

Cooking method is another factor that influence characteristics of cooked rice. Various studies suggest time and temperature of rice cooking affect physical quality of rice (Yamakura et al., 2005; Chakkaravarthi et al., 2008; Han and Lim, 2009; Tian et al., 2014). Higher cooking temperature will have effect on decreasing the physical quality and color of rice (Yamakura et al., 2005). According to Han et al. (2008), different cooking methods will affect the hydrolysis of starch.

In general, method of rice cooking can divided into two ways, namely conventional method and modern method. There are two stages in conventional method, there are boiling or scraping and steaming. Boiling or scraping stage consist 
of preparing water to boil and steam rice until it become rice. Meanwhile cooking rice with modern method use electricity or other non-natural instrument (Syafutri, 2016). Each cooking method will affect acceptability and chemical content.

At present there is still limited study comparing two methods of cooking various rice varieties. Brown rice and black rice that have unique characteristics (in terms of the composition of amylopectin and amylose) tend to be less acceptable by consumers (pera or less fluffy). In other hand, brown rice and black rice have better nutrients (vitamins, minerals, antioxidants, and fiber) than white rice (Monks et al. 2013). For this reason, research is needed to analyze effect of varieties and methods of cooking rice on sensory quality and consumer acceptability.

\section{METHOD}

This study use experimental design with factorial randomized design (two factors). Variable in this study are cooking method and rice variety as dependent variable and sensory quality as independent variables. Rice varieties used in study were semi-organic type (Berlian Sae white rice) / B1, non-organic type (Super Slyp white rice) / B2, brown rice / B3 and black rice / B4 . Cooking method used is conventional method (a combination of boiling and steaming) and modern method (rice cooker steaming). This research was arranged in factorial consist of 3 factors, that are based on variety (B) and cooking method (M). Variety factor consist of 4 parts, namely:

$\mathrm{B} 1=$ Berlian Sae white rice

B2 = Slyp Super white rice

$\mathrm{B} 3=$ brown rice

$\mathrm{B} 4=$ black rice

While the cooking method consist of 2 methods:

$\mathrm{M} 1=$ Conventional

M2= Rice Cooker (modern)

So that there are 8 treatment :

1. B1: Conventional method

2. B1: Modern method (rice cooker)

3. B2: Conventional method

4. B2: Modern method (rice cooker)

5. B3: Conventional method

6. B3: Modern method (rice cooker)

7. B4: Conventional method

8. B4: Modern method (rice cooker)
Study was conducted at Processing Laboratory and Organoleptic Laboratory, Department of Health Nutrition, Airlangga University for five months. Implementation of this study was approved by the Health Research Ethics Commission, Faculty of Public Health, Airlangga University under number 548/EA/KEPK/2018.

Rice from various varieties and processing methods were tested for sensory quality and acceptability using hedonic scale on 30 subjects of semi-trained panelist. Panelist have to fulfill inclusion criteria that are in the age range of 18-30 years, healthy at the time of data collection, not suffer from color blindness, and not experiencing impaired sensory function (colds, coughs, and others).

Sensory tests (quality characteristics) on rice are assessed based on indicators of color, aroma, taste, texture and overall. Purpose of sensory testing is to assess product quality characteristics based on panelist preferences as community representatives. The highest score on hedonic scale is expressed preference, and the lowest score indicates panelist dislike to sample. The purpose of quality test is to determine the effect of treatment on product quality characteristics. Assessment of quality characteristics consists of 5 choices as listed in table 1.

At each assessment session, water was provided for panelists to neutralize the taste on tongue. Number of samples presented is 15 gram each formula. Respondent fill out the inform consent to be panelist before conducting assessment. Data on organoleptic properties of the analysis results were statistically tested with analysis of variance (ANOVA) and continued with Duncan test.

\section{RESULT AND DISCUSSION}

\section{Cooking Properties}

Table 2 shows the ratio of water and rice ratio, optimal time and temperature in cooking rice. Based on table 2, brown rice and black rice require more water, both in conventional method and rice cooker. In addition, conventional methods require more time in cooking.

Brown rice and black rice have a higher water ratio for cooking in both methods. Twice more 
Table 2. Methods and Rice Variety

\begin{tabular}{cccccc}
\hline No & $\begin{array}{c}\text { Rice } \\
\text { Type }\end{array}$ & Method & $\begin{array}{c}\text { Water } \\
\text { Ratio }\end{array}$ & $\begin{array}{c}\text { Duration } \\
\text { (Minute) }\end{array}$ & $\begin{array}{c}\text { Optimal } \\
\text { Tempe- } \\
\text { rature } \\
\left({ }^{\circ} \mathbf{C}\right)\end{array}$ \\
\hline 1 & B1 & Conventional & $2: 1$ & 55 & 84 \\
2 & B1 & Rice cooker & $2: 1$ & 25 & 79 \\
3 & B2 & Conventional & $2: 1$ & 55 & 84 \\
4 & B2 & Rice cooker & $2: 1$ & 25 & 79 \\
5 & B3 & Conventional & $4: 1$ & 75 & 81.5 \\
6 & B3 & Rice cooker & $5: 1$ & 25 & 79 \\
7 & B4 & Conventional & $4: 1$ & 75 & 81.5 \\
8 & B4 & Rice cooker & $5: 1$ & 25 & 79 \\
\hline
\end{tabular}

water is needed for cooking brown rice and black rice compared to white rice. The optimum water ratio in cooking white rice is 1: 1.4-1.8 in Sintanur, Ciherang and IR 64 varieties (Subarna, 2017). Red and black rice have an ideal water ratio of 1: 3-4. Black rice has an absorption ratio highest water $(3.51 \mathrm{~g} / \mathrm{g})$, followed by brown rice $(3.20 \mathrm{~g} / \mathrm{g})$ and white rice $(2.99 \mathrm{~g} / \mathrm{g})$ (Lum, 2017) Presence of amylose and amylopectin affects the ability of food to absorb water, white rice has a low amylose content $(<20 \%)$ compared to black rice $(>20 \%)$. Amylose content is positively correlated with amylopectin content in rice. A linear structure in amylose allows rice to easily absorb water (Febriana et al., 2014).

The most important part of rice grain is endosperm which has main components of starch granules (amylose and amylopectin). Amylose is a straight chain polymer of glucose units (around 1000 units) that form crystalline. Amylose containing rice is giving texture of fluffier rice while rice with high amylose content has the nature of hard, dry and dry rice. This is due to ability of association between amylose structures to form rigid texture. The higher amylose content in rice grains, the higher water will absorbed to break down straight chain polymers so that rice is cooked and can be consumed (Luna et al., 2015).

Physical characteristics of brown rice and black rice are among the factors that also influence amount of water in cooking process. Rice used in this study were black rice and brown rice with broken skin. The cause of optimum absorption of water in brown rice and black rice is fat content and waxy coating on outer skin. External components of cuticle are hydrophobic which act as physical barrier to water absorption (Champagne et al., 1997; Mardiah et al., 2017).

Optimum cooking time used in conventional method is 55 minutes, while rice cooker method is 75 minutes, with higher optimum temperature needed in conventional method. Parboiled time ranges from 10-15 minutes with aim to optimize water absorption and accelerate heat transfer which give perfect texture to all parts of rice. In this study, parboiled was considered sufficient when water was absorbed. Time of parboiling considered as time when rice is heated on stove until water absorbed completely.

The optimal temperature in both methods ranges from $79-84^{\circ} \mathrm{C}$. If cooking is done above that temperature, there will be decrease in physical quality of amylose and amylopectin in rice (Yang et al., 2016). This affects ratio of amylose and amylopectin which will then affect texture and hardness of rice after cooking (Patindol et al., 2010). Under $40^{\circ} \mathrm{C}$, component that can be cooked is only water insoluble part, while water-soluble part can be absorbed optimally at $50^{\circ} \mathrm{C}-70^{\circ} \mathrm{C}$ (Yang et al., 2016). Optimum process of gelatinization of starch (amylose and amylopectin) occurs at $85^{\circ} \mathrm{C}$. Gelatinization is the process of enlargement of starch granules due to water absorption (Champagne et.al, 1997).

\section{Sensory Quality Test}

\section{Colour}

Colour is the outermost appearance that influences people initial preference for a product. Colour is the first attribute that is valued by consumers. Consumers will not be interested and do not provide a good assessment to other quality attributes if the colour of a product deviates from what it should be (Winarno, 2008; Andarwulan et al., 2011).

Based on Table 3, average panelist assessment of color indicators is in range of 2.07-4.37, which shows the range of panelist assessment from somewhat dislike to like. There is a significant difference based on type of rice on color indicator $(\mathrm{p}<0.05)$, while cooking method does not produce a significant difference between formulas. White rice (Slyp Super and Berlian Sae) has a higher acceptability than black rice and brown rice. 
Table 3. Result of Acceptance Test

\begin{tabular}{lccccc}
\hline \multirow{2}{*}{$\begin{array}{c}\text { Treat- } \\
\text { ment }\end{array}$} & \multicolumn{5}{c}{ Hedonic Parameter } \\
\cline { 2 - 6 } & Colour & Aroma & Taste & Texture & Overall \\
\hline \multicolumn{2}{l}{ Beras Berlian Sae } \\
RC & $4.03^{\mathrm{c}}$ & $3.73^{\mathrm{c}}$ & $3.50^{\mathrm{bc}}$ & $3.30^{\mathrm{b}}$ & $3.63^{\mathrm{c}}$ \\
$\mathrm{CV}$ & $4.17^{\mathrm{c}}$ & $3.67^{\mathrm{bc}}$ & $3.33^{\mathrm{abc}}$ & $3.33^{\mathrm{b}}$ & $3.73^{\mathrm{c}}$ \\
Beras Slyp super & & & & \\
RC & $4.10^{\mathrm{c}}$ & $3.27^{\mathrm{abc}}$ & $3.50^{\mathrm{bc}}$ & $3.33^{\mathrm{b}}$ & $3.73^{\mathrm{c}}$ \\
$\mathrm{CV}$ & $4.37^{\mathrm{c}}$ & $3.17^{\mathrm{abc}}$ & $3.77^{\mathrm{c}}$ & $3.97^{\mathrm{c}}$ & $3.80^{\mathrm{c}}$ \\
Beras merah & & & & \\
RC & $3.07^{\mathrm{b}}$ & $3.03^{\mathrm{ab}}$ & $2.90^{\mathrm{abc}}$ & $2.07^{\mathrm{a}}$ & $2.87^{\mathrm{b}}$ \\
$\mathrm{CV}$ & $2.07^{\mathrm{a}}$ & $2.77^{\mathrm{a}}$ & $2.60^{\mathrm{ab}}$ & $2.07^{\mathrm{a}}$ & $2.33^{\mathrm{a}}$ \\
$\mathrm{Beras}$ hitam & & & & \\
$\mathrm{RC}$ & $2.67^{\mathrm{b}}$ & $3.10^{\mathrm{abc}}$ & $2.47^{\mathrm{a}}$ & $2.50^{\mathrm{a}}$ & $2.80^{\mathrm{b}}$ \\
$\mathrm{CV}$ & $2.80^{\mathrm{b}}$ & $3.20^{\mathrm{a}}$ & $2.80^{\mathrm{ab}}$ & $2.50^{\mathrm{a}}$ & $2.47^{\mathrm{ab}}$ \\
\hline
\end{tabular}

Note : RC : Rice cooker, CV : conventional

* Superscript in the same column showed no significant differences $(\mathrm{p}>0,05)$.

Whereas brown rice with conventional methods has the lowest acceptability. Brown rice and black rice are less liked by people of Asia and Middle East. Indonesian people tend to prefer rice from white rice because of cultural factor (Suwanaporn and Linnemann, 2008).

Based on the quality characteristics test using hedonic scale (Table 4), there is a tendency for rice to be cooked with conventional method to produce bright and shiny colors while rice cooker method tend to be ordinary or blurry on black rice. This is due to slow heating time in conventional method so that it can maintain color quality. Slow heating can maintain color of outer portion of the rice so it looks brighter (Creed, 2001).

White rice tends to be shiny, while red rice and black rice tend to be opaque. This is due to differences in milling degree. White rice is milled rice that clean from epidermis and institutions, while red rice and black rice are mashed rice which separated only with the husk (Muchtadi and Sugiyono, 1992). During detachment, there was degradation of aleuron layer and embryo of rice grains. Degree of degradation of this layer is called milling degree. $70-80 \%$ milling degree indicate remaining $20 \%$ layer of aleuron that has not been degraded in rice grains (Indrasari, 2011). The higher the milling degree, the cleaner and shinier, so that the appearance of rice is more attractive (Subarna et al., 2017).

\section{Aroma}

Acceptance of product aroma begin when there are stimuli received by sense of smell due to physical and chemical properties of the molecule that produce odor (Gottfried, 2011). Stimulation received can be called remote tasting because the assessment of product preference is done by only smelling the aroma even though sample has not been seen. Food industry consider product evaluation are fast carried out through aroma testing to determine like or dislike (Soekarto, 1985).

Based on Table 3, average panelist rating aroma indicator range in 2.7-3.7, which show panelist acceptance range from somewhat dislike to like. There was significant difference based on type of rice on aroma indicator $(\mathrm{p}<0.05)$, while cooking method did not produce significant difference. Berlian Sae white rice with rice cooker method has the best aroma, while brown rice with conventional method has the lowest acceptance.

Based on quality characteristics test (Table 4), average rice has normal or neutral aroma according to natural aroma of rice. According to panelists, Berlian sae and Slyp Super type white rice has fragrant aroma while black rice tend to be musty with conventional processing methods. Genetic factors are one of the cause of differences in aroma attribute in food ingredient (rice). Other factors

Table 4. Quality Characteristic Test Result

\begin{tabular}{|c|c|c|c|c|}
\hline \multirow{2}{*}{ Treatment } & \multicolumn{4}{|c|}{ Hedonic Parameter } \\
\hline & Colour & Aroma & Taste & Texture \\
\hline \multicolumn{5}{|c|}{ Berlian Sae Rice } \\
\hline$R C$ & Neutral & Fragrance & Neutral & Neutral \\
\hline $\mathrm{CV}$ & $\begin{array}{l}\text { Bright } \\
\text { Shiny }\end{array}$ & Fragrance & Neutral & Fluffy \\
\hline \multicolumn{5}{|c|}{ Slyp Super Rice } \\
\hline $\mathrm{RC}$ & Neutral & Fragrance & Neutral & Neutral \\
\hline $\mathrm{CV}$ & $\begin{array}{l}\text { Bright } \\
\text { Shiny }\end{array}$ & Fragrance & $\begin{array}{l}\text { A little } \\
\text { sweet }\end{array}$ & Fluffy \\
\hline \multicolumn{5}{|l|}{ Browin Rice } \\
\hline $\mathrm{RC}$ & Neutral & Neutral & Tasteless & Neutral \\
\hline $\mathrm{CV}$ & Neutral & Musty & Tasteless & Neutral \\
\hline \multicolumn{5}{|l|}{ Black Rice } \\
\hline $\mathrm{RC}$ & Buram & Neutral & Tasteless & Less fluffy \\
\hline $\mathrm{CV}$ & Neutral & Musty & Tasteless & Less fluffy \\
\hline
\end{tabular}

Keterangan: RC : Rice cooker, CV : Conventional 
that can affect aroma are rice growth condition and post-harvest treatment (Cagampang et al., 1973). According to Wongpornchai et al. (2004) there are more than one hundred components in rice that contribute to quality characteristics.

Milling degree is thought to affect the aroma of rice. The higher the milling degree, the less the evaporation of substances contained in the aleuron. These substances will affect colour quality of rice. Whereas rice naturally have a neutral to fragrant aroma. The cause of musty smell in rice because there are compounds resulted from oxidation of fat with air. Oxidized compounds give rancid odor characteristics. Black rice and brown rice have a layer of hydrophobic fat in some outer skin that can be oxidized (Astawan and Wresdiyati, 2004).

\section{Taste}

Taste is an accumulation of various stimuli obtained from sensory perception and digestive stimulation due to chemical stimulation from food, drinks, or herbs in mouth (Melton, 2006). Based on Table 3, panelist response to taste are in range of 2.4-3.7, showing the range of panelist rating from somewhat dislike to like. There was a significant difference based on type of rice on flavor indicator $(\mathrm{p}<0.05)$, while the method did not produce any significant difference between formulas. Super Slyp white rice with conventional methods has higher taste acceptance, followed by other types of white rice. Black rice with a rice cooker method has the lowest acceptability among all formula.

Based on quality characteristics test (Table 4), average rice has a normal or neutral taste according to natural taste of rice. According to panelist, Berlian sae and Slyp Super rice types have ordinary taste so they tend to be rather sweet, while black and red rice tend to be bland. Conventional cooking method influence the taste of rice so that rice taste sweeter. Long heating affect taste of rice. Slow and long period heating affect characteristics of simple glucose contained in rice starch (Kohlwey, 1995). In addition, ratio of amylose and amylopectin also affect taste of rice. Amylose content has negative correlation with taste attribute. High amilosa level in rice gives lower preference of taste, because taste of rice will be more tasteless than rice with low amilosa level.

\section{Texture}

Texture is defined as multidimensional property, while the most commonly used parameters for rice are hardness and stiffness (Juliano et al, 1983). Some factors related to rice texture are amylose content (Cameron and Wang, 2005, Jinorose et al., 2014) and protein content (Saleh and Meullenet, 2007; Mestres et al., 2011).

Texture profile analysis was developed to simulate texture properties by human senses, especially during mastication by teeth. Based on Table 3, panelist response to texture ranged on scale of 2-3.9 showing the range of panelist rating range from dislike to like. Super slyp white rice has the highest acceptability for texture followed by other white rice. While brown rice has the lowest acceptability for texture testing.

Based on quality characteristics test (Table 4), average rice has less fluffy texture, normal to fluffier according to the natural texture of rice. According to panelists Slyp Super type rice cooked by conventional methods has fluffier textures, while berlian sae variety have normal textures, and black rice has less fluffy texture.

Hardness or texture of rice is positively correlated with amylose content in its composition (Yu et al., 2009). Rice with high amylose has ability to break down with water and form coating layer (coating film) that affects hardness. High amylose content will cause rice to have ability to form hydrogen bonds greater than the ability to amylopectin (Juliano, 1983). Black rice has the highest amylose content $(>20 \%)$, while white rice has lower amylose content $(<20 \%)$. Characteristics of rice with dominant amylose content are nonsticky and can expand during cooking. Rice with moderate amylose content, generally has fluffier texture (Damardjati, 1995). This show that amylose content is positively correlated with water content. Unbranched amylose structure causes water to be more easily absorbed by granules, so black rice has less fluffy texture according to panelist rating (Febriana et al. 2014). Consumers in Indonesia are likely to choose rice with low to moderate amylose content $(\leq 25 \%)$. This is because consumers prefer rice with fluffier texture (Haryadi 2006).

Slyp Super Rice and Berlian Sae rice cooked with conventional methods have fluffier texture and are different compared to other rice types. Duration 


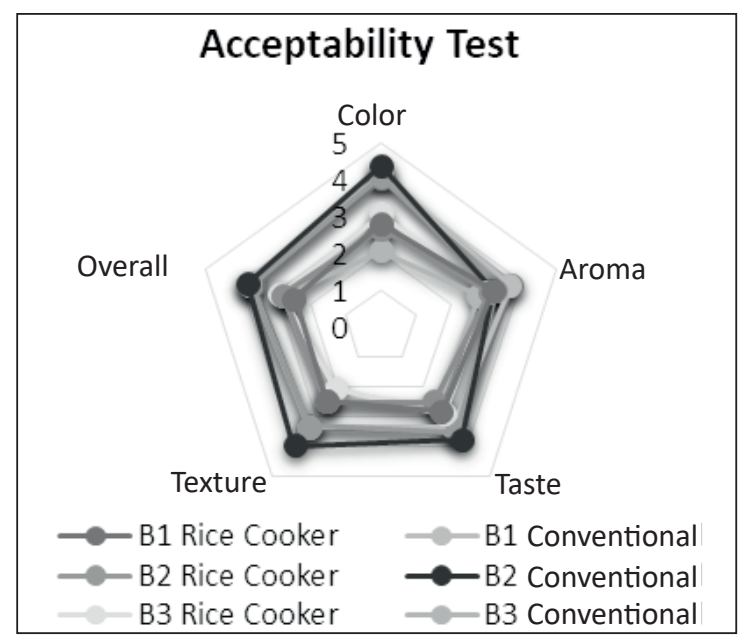

Figure 1. Radar Chart of Rice Acceptability Test

of heating affect texture of rice. Slow heating and long cooking period give effect to the texture of rice (Jualiano, 1983). This is in accordance with conventional method principle. Rice soaking time with water in conventional method affect amylose content. Long soaking time will cause amylose level to decrease so that rice tend to be fluffier (Hasbullah et al., 2013).

\section{Acceptability}

Based on an evaluation of overall acceptability test (Figure 1), the chosen formula with the highest indicator is the white Slyp Super rice cooked with conventional method. White rice has the highest value in term of colour, taste and texture. The best aroma is owned by Berlian Sae rice cooked with modern method. Figure 1 present trends of factors affecting panelist interest data in different rice type and method. Colour variable is the most prominent range affecting panelist interest, then followed by other variables.

Further research efforts are needed to improve quality of rice, especially on colour indicator. Although sensory and acceptability tests are more subjective in terms of consumer acceptance, this is important in further product development, because final assessment of rice quality lies in processed product quality, especially rice that is preferred by consumers (Akhyar, 2009).

\section{CONCLUSION}

Panelist acceptance of study sample is influenced by rice type and cooking method.
White rice (Slyp Super and Berlian Sae) has a higher acceptability than brown rice and black rice. Conventional cooking method tend to be preferred because it has more attractive colour and texture. Rice with conventional processing methods tend to be brighter and fluffier. Further research is needed in designing the standardization of cooking method to optimize quality of rice, especially related to amount of water and length of time for processing. Further research is needed to establish a standard method for cooking rice, especially red and black rice to increase consumer acceptance.

\section{REFERENCES}

Akhyar. (2009). Pengaruh proses pratanak terhadap mutu gizi dan indeks glikemik berbagai varietas beras di Indonesia. Tesis. Bogor: Institut Pertanian Bogor. Retrieved from: http:// repository.ipb.ac.id/handle/123456789/41365.

Andarwulan, N., Kusnandar, F \& Herawati, D. (2011). Analisis Pangan. Jakarta: Dian Rakyat.

Astawan, M dan T, Wresdiyati. 2004. Sehat Bersama Aneka Serat Pangan Alami. Solo: Tiga Serangkai.

Cagampang, Gloria B, C.M. Perez, dan B.O. Juliano. (1973). A gel consistency test for eating quality of rice. Journal of the Science of Food and Agriculture 24 (12),: 1589-1594. doi: $10.1002 /$ jsfa. 2740241214.

Cameron, D.K., \& Wang, Y.J. (2005). A better understanding of factors that affect the hardness and stickiness of long-grain rice. Cereal Chem, 82, , 113- 119. doi : 10.1094/CC-82-0113.

Chakkaravarthi, A., Lakshmi, S., Subramanian, R., \& Hegde, V.M. (2008). Kinetic of cooking unsoaked and presoaked rice. Journal of Food Engineering, 84, 181-186. doi : 10.1016/j. jfoodeng.2007.02.061.

Champagne, E. T., Karen L. B., Bryan T. V., Bill, D. W., Anna, M. M., Franklin, E. B., ... David, K. (1997). Effects of drying conditions, final moisture content, and degree of milling on rice flavor. Cereal Chemistry, 74 (5), 566-570. doi: 10.1094/CCHEM.1997.74.5.566.

Creed, P. G. \& Crowshurt, D. G. (2001). Effect of cooking methods and variety on the sensory quality of rice. Food service technology journal, 1(3-4),: 133 - 140. doi: 10.1046/j.14715740.2001.00019.x.

Damardjati, D. S. (1995). Karakteristik sifat standarisasi mutu beras sebagai landasan 
pengembangan agribisnis dan agroindustri padi di Indonesia. Orasi Pengukuhan Ahli Peneliti Utama. Balai Penelitian Bioteknologi Tanaman Pangan, Bogor.

Febriana A, Rachmawanti D, \& Anam C. (2014). Evaluasi kualitas gizi, sifat fungsional, dan sifat sensoris sala lauak dengan variasi tepung beras sebagai alternatif makanan sehat. Jurnal Teknosains Pangan, 3(2), 28-38. Retrieved from : https://jurnal.uns.ac.id/teknosains-pangan/ article/view/4638/4026. .

Gottfried, J. A. (2011). Neurology of sensation and reward. Boca Raton (FL): CRC Press/ Taylor\&Francis.

Han, J.A., \& Lim, S.T. (2009). Effect of presoaking on textural, thermal, and digestive properties of cooked brown rice. Cereal Chemistry, 86, 100105. doi: 10.1094/CCHEM-86-1-0100.

Han, S. H., Lee, S.W., \& Rhee, C. (2008). Effects of cooking methods on starch hydrolysis kinetics and digestion-resistant fractions of rice, European Food Research and Technology, 227 ((5)), :1315-1321. doi: 10.1007/s00217-0080846-6.

Haryadi. 2006. Teknologi Pengolahan Beras. Yogyakarta : Penerbit UGM Press.

Hasbullah, R. (2013). Pengaruh lama perendaman terhadap mutu beras pratanak pada varietas IR 64. Jurnal Keteknikan Pertanian, 27(1). doi : 10.19028/jtep.27.1.53-60

Indrasari, S.D. (2011). Pengaruh penyosohan gabah dan pemasakan terhadap kandungan vitamin B beras merah. Jurnal Penelitian Pertanian Tanaman Pangan. 30(3):182-188. Retrieved from : http://ejurnal.litbang.pertanian.go.id/ index.php/jpptp/article/view/3024/2646

International Rice Research Institute (IRRI). (1991). Rice grain marketing and quality issues. Selected papers from the International Rice Research Conference Seoul, Korea. Philippines: IRRI.

Jinorose, M., Prachayawarakorn, S., \& Soponronnari, S. (2014). A novel image-analysis based approach to evaluate some physicochemical and cooking properties of rice kernels. $J$ .Food Eng, 124, 184-190. doi : 10.1016/j. jfoodeng.2013.08.009

Juliano, B. O. \& Perez, C. M. (1983). Major factors affecting cooked milled rice hardness and cooking time. J. Texture Stud, 14, 235-243. doi : 10.1111/j.1745-4603.1983.tb00346.x

Kementerian Pertanian. (2017). Statistik pertanian 2017. Jakarta: Kementan.
Kohlwey DE, Kendall JH, Mohindra RB (1995). Using the physical properties of rice as a guide to formulation. Cereal Foods World 40, 729-32.

Lum, M. S. (2017). Physicocemical characteristic of different rice varieties found in Sabah, Malaysia. Transactional on Science and Technology, 4(2). 68-75. Retrieved from : http://tost.unise.org/ $\mathrm{pdfs} / \mathrm{vol} 4 / \mathrm{no} 2 / 4 \times 2 \times 68 \times 75 . \mathrm{pdf}$

Luna, Prima., Heti Herawati., sri Widowati., Aditya B. Prianto. (2015). Pengaruh kandungan amilosa terhadap karakteristik fisik dan organoleptik nasi instan. Jurnal Penelitian Pascapanen Penelitian 12 (1), 1-10. doi: 10.21082/jpasca. v12n1.2015.1-10

Lyon, B. G., Champagne, E. T., Vinvard, B. T., \& Windham, W. R. (2000). Sensory and instrumental relationships of texture of cooked rice from selected cultivars and postharvest handling practices. Cereal Chem, 77, 64-69. Doi : 10.1094/CCHEM.2000.77.1.64

Mardiah, Z., Handoko, D. D., Septianingrum, E., $\&$ Kusbiantoro, B. (2017). Improvement of red rice eating quality through one-time polishing process and evaluation on itsphenolic and anthocyanin content. International Journal of Agriculture, Forestry and Plantation, 5(6). Retrieved from : http://ijafp.com/wp-content/ uploads/2017/10/AG-9.pdf

Mestres, C., Ribbeyre, F., Pons, B., Fallet, V., \& Matencio, F. (2011). Sensory texture of cooked rice is rather linked to chemical than to physical characteristics of raw grain. J Cereal Sci,53, 81-89. doi : 10.1016/j.jcs.2010.10.001

Muchtadi, T.R. dan Sugiono. (1992). Ilmu Pengetahuan Bahan Pangan. Departemen Pendidikan dan Kebudayaan. Direktorat Jenderal Tinggi Pusat Antar Universitas Pangan dan Gizi. Bogor: Institut Pertanian Bogor.

Patindol, J., Gu X., \& Wang, Y.J. (2010). Chemometric analysis of cooked rice texture in relation to starch fine structure and leaching characteristics. Starch-Starke, 62, 188-197. doi: 10.1002/star.200900181

Saleh, M. I., \& Meullenet, J. F. (2007). Effect of protein disruption using proteolytic treatment on cooked rice texture properties. J. Texture Stud, 38, 423- 437. doi : 10.1111/j.17454603.2007.00105.x

Soekarto, TS. (1985). Penilaian Organoleptik untuk Industri Pangan dan Hasil Pertanian. Bharata Karya Aksara; Jakarta 
Subarna, Suroso, Budijanto S., \& Sutrisno. (2017). Pengembangan metode menanak optimum untuk beras varietas Sintanur, IR 64 dan Ciherang. Prosiding Seminar Nasional Teknologi Inovatif Pasca Panen untuk Pengembangan Industri Berbasis Pertanian. Retrieved from : http:// repository.ipb.ac.id/handle/123456789/26076

Suwannaporn, P., \& Linnemann, A.R. (2008). Consumer preferences and buying criteria in rice: a study to identify market strategy for Thailand jasmine rice export. Journal of food product marketing. Vol 14(4):33-53. doi : 10.1080/10454440801986348

Syafutri, M. I., Pratama, F., Syaiful, F., \& Faizal, A. (2016). Effects of varieties and cooking methods on physical and chemical. Rice Science. 23(5), :282-286. doi : 10.1016/j.rsci.2016.08.006

Tian, Y., Zhao, J., Xie, Z., Wang, J., Xu, X., \& Jin, Z. (2014). Effect of different pressure-soaking treatments on color, texture, morphology and retrogradation properties of cooked rice. Food Science and Technology Journal, 55, (368-373). doi: 10.1016/j.lwt.2013.09.020

Wada, M., Tsubone, Y., Hamanhi \& Ogata, T. (2006). Evaluation and use of physicochemical properties as index trains for selecting rice cultivars with extremely high palatability. Jpn. J. Crop Sci, 75, 38-43. doi: 10.1626/jcs.75.38

Winarno, F.G. (2008). Kimia Pangan dan Gizi: Edisi Terbaru. Jakarta.

Wongpornchai, S., Dumri, K., Jongkaewwattana, S., \& Siri, B. (2004). Effect of Drying Methode and Storage Time on the Aroma and Milling Quality of Rice (Oryza sativa L.) cv. Khao Dawk Mali 105. Journal Food Chemistry 87(3) : 407-414. doi: 10.1016/j.foodchem.2003.12.014

Yadav, R. B., Khatkar, B. S., \& Yadav, B. S. (2007). Morphological, physicochemical and cooking properties of some Indian rice (Oryza sativa L.) cultivars. J Agric Technol, 3(2): 203-210. Retrieved from: http://www.ijat-aatsea.com/ pdf/Nov_V3_no2_07/5-IJAT2007_14-P\%20 203-210.pdf

Yamakura, M., Haraguchi, K., Okadome, H., Suzuki, K., Tran, U., Horigane, A.K.,... Ohtsubo, K.(2005). Effects of soaking and high-pressure treatment on the qualities of cooked rice. Journal of Applied Glycoscience, 52, 85e93. doi: 10.5458/jag.52.85

Yang, D.S., Lee, K.S., \& Kays, S.J. (2010). Characterization and discrimination of premiumquality, waxy, and black pigmented rise based on odor-active compounds. J. Sci Food Agric, n/a. doi: 10.1002/jsfa.4126. doi: 10.1002/jsfa.4126

Yang, L., Sun, Y.H., Liu, Y., Mao, Q., You, L.M., Hou, J.M., \& Ashraf, M.A. (2016). Effect of leached amylose and amylopectin in rice cooking luquidon texture and structureof cooked rice. Brazilian Archives of Biology and Technology, 59. doi: 10.1590/1678-43242016160504

Yu, S.F., Ma, Y., \& Sun, D.W. (2009). Impact of amylose content on starch retrogradation and textureof cooked milled rice during storage. Journal of Cereal Science, 50,139-144. doi: 10.1016/j.jcs.2009.04.003 